\title{
Abstract
}

\section{Jump to section}

- Introduction

- Origins of the wake tradition

- The significance of the keening woman

- Wake amusements

- Female vocality and the liminal

- Conclusion

In the traditional Irish ritual of the merry wake, death and sexuality were tied closely together. The mourning for the deceased was accompanied by excessive feasting and drinking while wake games of an overtly sexual nature were performed in the presence of the corpse. This voluptuous, uninhibited behaviour exhibited during the death ritual echoes the state of the mná caointe or keening women who inhabited a liminal realm between the living and the world of the dead for the duration of the mourning period. This 'divine madness' allowed keeners to express the collective outpouring of grief through their voices and bodies, and lead the community in a public expression of sorrow and lament. This article will examine the significance of the mná caointe in the wake ritual, in particular the power of the female voice in transcending the strictures of the world of the living and the brief period of licence which then ensued. As well, it will explore the connection between the role of the keener and the anarchic nature of the merry wake amusements, where the embodied voice leads the community to a place where the social order is suspended, and the chaotic nature of death is confronted.

\section{Introduction}

The primal forces of eroticism and death are bound together in many cultures and texts. From Georges Bataille's exploration of death and sensuality, to the notion of the operatic kiss of 'love and death' (Brochmeyer 2010), to the lustful murder ballads of contemporary musician Nick Cave, we find death and eroticism in uneasy communion. The focus for this article, then, is the relationship between death, revelry, and sexual exuberance, specifically in the traditional Irish ritual of the merry wake, where death and sexuality were bound closely together for the mourning period.

This ritualistic practice of lamenting the deceased was accompanied by an excessive consumption of alcoholic drink and food in a wild celebration and affirmation of life. Wake games, which had overt sexual connotations, were performed in the same space as the laidout corpse, juxtaposing the finality of life with a period of sexual licence where mourners indulged in lewd and lascivious 'amusements'. Many of these games were played by men and women enacting antediluvian ceremonies which included cross-dressing and nakedness, practices which persisted despite the advent of Christianity and the moral reforms that ensued. The voluptuous and uninhibited behaviour exhibited during the ritual echoes the state of the mná caointe 1 (keening women) who inhabited a liminal realm between the living and the world of the dead for the duration of the mourning period. This 'divine madness' allowed keeners to express the collective outpouring of grief through their voices and bodies, and lead the community in a public expression of sorrow and lament.

This article draws on primary resources collected during my research in Ireland as well as a range of secondary sources by acknowledged experts in the field of keening and wake ritual. 
Due to the fact that this ancient practice has all but disappeared, it has also been necessary to include field recordings or reports of field recordings to support my argument. I will examine the origins of the wake tradition, focusing particularly on the merry wake and the power of the keening woman, in order to explore the connection between the role of the keener and the anarchic nature of wake 'amusements', in which the embodied voice leads the community to a place where the social order is suspended, and the chaotic nature of death is confronted. While there are first-hand reports of death rituals in the eighteenth and nineteenth century (Campbell and Watkinson 1778; Croker 1969 [1824]; Carleton 1990 [1842-44]; Prim 185253), detailed collections of wake games (O Súilleabháin 1967), analyses of death customs and their cultural relevance (Doyle 1988; Ó Crualaoich 1998; O Madagáin 2006; Ridge 2009), and the relevance of the mná caointe or keening women (Bourke 1988, 1993; Lysaght 1996, 1997, 2003), little has been written on the connection between the power of the female voice during the death ritual and the ensuing licentious behaviour exhibited at merry wakes. This paper will explore the possibility that the keening woman's voice created an inversion where revelry and erotic games were enacted in the presence of the dead person as part of a cathartic celebration so that the community could resume its normal pattern of life.

\section{Origins of the wake tradition}

In order to understand the importance of the death ritual in Ireland, I will examine the origins of the rite and its connection to Bakhtin's (1968) notion of the 'carnival spirit'. Waking the dead stems from an ancient Irish custom which persisted well into the twentieth century, in which the body of the deceased was laid out in the family home in order for relatives, friends, and neighbours to pay their final respects and for the corpse to be keened, or lamented, so that the spirit might pass safely to the next world. An integral part of this rite was the presence of the bean chaointe, or keening woman, who led the community in the collective outpouring of grief through the sung lament or caoineadh which was regarded as essential in order to honour the deceased. Angela Bourke $(\underline{1993}, 163)$ opines that 'caoineadh may be seen as the verbal and musical aspect of a traditional "theatre of death", the wake and funeral, over which certain skilled women presided and through which the entire community adjusted to death and loss'. Furthermore, the keening woman used her 'appearance, her voice and her poetry to work on the emotions of her audience' (165) and to lead them through the cathartic experience of grief.

Though mourning usually is viewed as a sorrowful time, the Irish merry wake presented another aspect of the death ritual, and included music, dancing, games, tricks, riddles, and storytelling, as well as the consumption of alcohol and food. It must be stressed that this type of celebration only occurred when an older person died as it was seen as a chance to socialize, particularly by younger people in the community who 'could have a party because everyone brought their bits of food and drink and there were fun and games' (personal communication, Quealy 2009). Seán Ó Súilleabháin (1967, 26), author of Irish Wake Amusements, notes that wakes for older people were 'far merrier than weddings', with the young people looking forward to the death of an old man or woman so as to provide them with a night of 'turf-throwing and frivolity' while Anne Ridge (2009, 47) suggests that they were 'social occasions: games, storytelling, eating, drinking and smoking were all features of the wake'. The notion of hilarity at such a solemn time exemplifies the topsy-turvy nature of the ritual where laughter was employed to overcome the fear of death 'for it knows no inhibitions, no limitations' (Bakhtin 1968, 90). Also, wake games were a demonstration of the community's vigour in the face of death and helped to restore the social order and guarantee continuing stability. Ó Súilleabháin $(1967,174)$ proposes that the games played in the domestic wake may be related to the grand funeral games held for kings and heroes, 
suggesting that 'the games at a wake, as well as the keening, are descended from the same ultimate source as the cluiche caointeach (game of lamentation) which took place when a great warrior died in ancient Ireland'. This notion would explain many of the obscure aspects of the rites of passage observed in household wakes, as well as the sexual overtones of some of the games.

The connection between the keen (caoineadh) and the liminal world can be traced back to the importance of the female voice and its connection with the ancient rituals associated with the pagan feast of Samhain (November 1) which marked the beginning of the Celtic New Year. During this time, the great burial tombs, such as New Grange, were opened, and the souls of the Dead returned to dance with the living as funeral games (na cluiche fuait) were celebrated in their honour (Doyle 1988). Mary Agnes Doyle (1988) in her dissertation, Games of Lamentation: the Irish Wake Performance Tradition, suggests that the mythological Fomoire, a race of one-eyed, one-legged giant women, which stood between the Irish world of manifestation and the realm of the unknown, represented a liminal, half-seen quality which is the personification of the concept of duality, or 'other' associated with the sound of the keening woman. This concept of straddling the worlds is also apparent in Irish mythology where the shamanistic posture of standing on one leg, putting one hand behind the back and closing one eye evokes a place between the worlds. When the souls of the dead were reanimated and remembered by the performance of the keen or caoineadh during Samhain, the sphere between past and future, the dead and the quick was ruptured and the natural order was destroyed; cabbages were thrown at doors, smoke was blown through keyholes, chimneys were blocked with turf, horses were stolen, and carts overturned (Rees and Rees 1961). The participants' everyday respectful boundaries of the self-contained body were abandoned in dance, fighting, thievery, and erotic play (Doyle 1988). What seemed like chaos was actually the death of respectability reflecting the notion of a carnivalesque reversal and transgression of social norms for the delineated period of the wake.

Accompanying the rites associated with mourning was the concept of potlatch, a ritual squandering of goods with 'honour, pomp, braggadocio and challenge' as opposed to the 'ordinary world of toil and care' (Huizinga 1955, 60). In the ancient funeral games held for kings and heroes, one of the forms of potlatch was demonstrated by excessive banqueting, a sign of the monarch's largesse, a tradition echoed in the merry wake where feasts were provided to the mourners and the funeral meats were consumed to excess. This excessive eating and drinking at the funeral banquet bears out Bakhtin's $(\underline{1968}, 283)$ notion that folktales end with a feast rather than a death, thereby disturbing the notion of social order because 'the end must contain the potentialities of the new beginning, just as death leads to a new birth'. Doyle $(1988,125)$ states that the wake was the central festival where the 'social values of generosity, the ability to provide to excess, and competitive reciprocity are displayed'; however, this munificence 'establishes a debt, a challenge to exceed'. This notion of excess and competition extended to the mná caointe, or keening women, and explains, in some part, the reason why they vied over lamenting the corpse in wild excesses of emotion, each attempting to outdo the other in volume and histrionics (Ó Súilleabháin 1967, 137).

\section{The significance of the keening woman}

The cultural significance of the keen in the funerary rite (and the rituals associated with the keening woman) can be established by tracing its genealogy in Irish lore and its intrinsic link to Irish spirituality. The first sounds of the keen in Ireland were attributed to Brigit, the Triple Goddess of Irish mythology who keened when her son, Ruadan, was killed by the Fomoire. This was said to be the first time that weeping and lamentation were heard in Ireland (Squire 1979 [1905]). The connection between sovereignty goddesses and the lament tradition is said 
to have inspired the song of another supernatural being, the Bean sí, (Banshee) or Woman of the Otherworld (Lysaght 1996). This mythical creature, portrayed as having long flowing hair, is associated with mortality, and her keening is purported to be heard through the countryside prior to a death. Her connection with sovereignty goddesses is 'embedded in lore of early blood drenched battles between Celtic ancestors and invading armies' (deFaoite 2004, 127). She was once seen as a 'patron goddess and personification of the land' but Lysaght $(1996,243)$ suggests that she is now seen as a 'family messenger of death - "one of your own” coming to announce death, and to accompany you... across the great divide into the company of your ancestors'.

Breandán Ó Madagáin (2006) in his radio programme entitled 'Hags, Queens and Wisewomen', discusses this traditional world view of Irish rural communities in relation to the figure of the supernatural female, who is an overarching presence both in life and in fiction.

This supernatural female figure was invoked in times of crisis and transition such as birth and death. Flesh and blood women would step up and take on, not the role of the supernatural female, but a role of service to the community which was motivated and inspired, reinforced and given meaning to by story and ritual. One of these women was the bean chaointe or keening woman.

This 'flesh and blood' woman was an essential presence at funerary rites to ensure that the deceased departed to the Otherworld, and that the journey was as smooth as possible. If the keen broke out too early, the 'devil's dogs' were alerted and the soul could lose its way. However, the pivotal role she fulfilled was to lead the community in the public expression of sorrow and grief and to carry the group along with her in a type of catharsis. One of the most powerful accounts of caoineadh around the turn of the twentieth century was recorded by the Irish playwright John Millington Synge (1979, 37-8), who was visiting the Aran Islands off the west coast of Ireland. The isolation of the Gaelic community and the absence of a priest resulted in an extraordinary performance of the older women of the community in the face of death.

While the grave was being opened the women sat among the flat tombstones, bordered with a pale fringe of early bracken and all began the wild keen, or crying for the dead. Each old woman, as she took her turn in the leading recitative, seemed possessed for the moment with a profound ecstasy of grief, swaying to and fro, and bending her forehead to the stone before her, while she called out to the dead with a perpetually recurring chant of sobs. All round the graveyard other wrinkled women, looking out from under the deep red petticoats that cloaked them, rocked themselves with the same rhythm, and intoned the inarticulate chant that is sustained by all as an accompaniment... The morning had been beautifully fine, but as they lowered the coffin into the grave, thunder rolled overhead, and hailstones hissed among the bracken. In Inishmaan one is forced to believe in a sympathy between man and nature, and at this moment, when the thunder sounded a death-peal of extraordinary grandeur above the voices of the women, I could see the faces near me stiff and drawn with emotion. When the coffin was in the grave, and the thunder had rolled away across the hills of Clare, the keen broke out again more passionately than before.

Elizabeth Tolbert $(\underline{1994}, 192)$ notes that in her studies of Finnish-Karelian lament, 'the quality of the lamenter's crying voice points to the somatization of grief, a process that is only possible through the experiences of the individual body. Thus the quality of the voice itself is crucial to the negotiation between the personal and the collective'. It could be viewed in some societies that crying denotes weakness and loss of control; however, Tolbert asserts that 'lament performance allows for the creation of women's "affective enclaves", gender defined spaces of protest, solidarity and affirmation that maintains separateness yet also allows for influence and access to social power'. This notion of 'affective enclaves' is evidenced in 
Ireland where the control of the death ritual was managed solely by women, with the priest only attending at the official burial service in the church. Gearóid Ó Crualaoich $(\underline{1998}, 176)$ notes that, though the funerary rite was ostensibly a Catholic ritual, it was 'marked by a vivid native and localised apprehension of the otherworld and of death that drew on a cosmology and a religious sensibility deriving from a native, or pagan, or Celtic world view alternative to the Christian one'. The role of keener provided a licence for social comment and criticism of any number of people including the corpse, the clergy, and the local constabulary. The tradition of upbraiding the dead, calling on them to arise and plough their fields or accusing them of ill-treatment of their loved ones had a cathartic affect on the immediate family giving them a chance to air frustrations with the deceased and allowing them to move on with their lives.

\section{Wake amusements}

The crying voices of the mná caointe provided a liminal space for the chaos imposed by death to intrude into the world of the living, creating an inversion where horseplay and sexual licence is tolerated, and even encouraged, for the entertainment of the mourners and the corpse. This, in turn, enabled the community to indulge in anarchic behaviour which would not have been otherwise tolerated in a Christian society. It is a time of 'uncharacteristic behaviour symbolising a world reduced to chaos'; however, these 'funeral reversals' perform a dual role. They are designed to usher the deceased to the otherworld and away from the land of the living as well as representing the 'formlessness that characterises the heart of the funeral process' (Grainger 2010, 18). Holst-Warhaft $(2000,65)$ proposes that the 'displays of grief, the games of skill or sexual conquest, the obscene gestures were all addressed to the single silent watcher, the constant reminder of the common fate of the players'. Merry wake games were enacted in the presence of the corpse who was seen as a viable member of the community for the period of the wake. The games reassured the deceased of 'his popularity' and of 'his continuing presence as one of the company' (Ó Súilleabháin 1967, 172). The corpse, from the time of death until the grave was sealed, was kept near the living at all times (Morris 1938) as it was believed that the soul continued to inhabit the body and that it appreciated the company of the living. This makes it easier to understand occasions where the corpse was dealt a hand of cards, or had a pipe put in its mouth or was taken onto the floor to join the dancers (O Súilleabháin 1967, 172). In parts of Ireland, it was a commonly-held belief that the deceased retained the power of hearing until it was interred and the priest had thrown three shovels of earth on the coffin (Lysaght 1997, 69). It is therefore understandable that some people were desperate to save every penny they could in order to afford a lavish wake. Antiquarian Thomas Crofton Croker (1969 [1824], 210) noted that:

When advanced in life, it is usual, particularly with those who are destitute and friendless, to deny themselves the common necessaries of life and to hoard up every trifle they can collect for the expenses of their wake and funeral. Looking forward to their death as to a gala given by them to their acquaintances, every possible preparation made for rendering it, as they consider, 'creditable'.

The survivors did everything in their power to placate the dead, which included rituals such as leaving an open window in the wake house so that the deceased's soul could leave the gathering; covering or turning mirrors to the wall so as not to distract the spirit of the dead person; removing any obstacle such as furniture, and in some places even objects such as a knives, which may harm the soul as it departed (Ridge 2009, 23-4). By the nineteenth century, the strategy of including the dead as an active participant in the merry wake ritual was 'in clear opposition to the hegemony of official religion, in a festive-carnivalesque state where everything is united - good and evil, day and night the sacred and the profane' 
(Narváez 2003, 114). Doyle $(\underline{1988,121)}$ claims that the 'boisterous, festive atmosphere retains the quality of the heroic potlatch' of the ancient funeral games discussed earlier in this chapter, with 'pranks, athletic competitions, faction fighting and verbal duelling matches'. The humour in the merry wake is the subject of Finnegan's Wake by James Joyce who famously punned on the word 'funeral', referring to it as a 'funferall', suggesting the suspension of propriety and a period of abandon for the limited time of the mourning rites. In The Irish Comic Tradition, Vivian Mercier $(1962,49)$ describes wakes as the possible source of the 'Irish propensity for macabre humour', whereas William Wood-Martin (1901, 321), who had the opportunity of collecting first-hand accounts, described 'many wanton orgies which disgraced wakes, particularly in the province of Munster’. As previously mentioned, the anarchic nature of the wake created a temporary inversion where features of carnival, such as sexual abandon, gluttony and cross dressing, were encouraged. In 1853, historian John Prim observed a wake game where 'female performers attired themselves in men's clothes and behaved very strangely' (344).

As previously stated, wakes were eagerly anticipated as social occasions, as observed by Thomas Campbell $(\underline{1778}, 210)$ who stated that:

wakes are meetings of merriment and festivity, to which they resort from far and near. The old people amuse themselves in smoking tobacco, drinking whiskey, and telling stories in the room with the corpse; whilst the young men, in the barn, or some separate apartment, exhibit feats of activity; or, inspired by their sweethearts, dance away the night.

Seán O Súilleabháin (1967), in Irish Wake Amusements, lists over 130 specific wake amusements, or games, which were played at wake houses in Ireland. These games are part of a large collection of performative modes which could be violent and very competitive with 'mock battles, mock trials, mock deaths, mock corpses' (Grainger 2010, 19). Wake activities, including practical jokes where the corpse was seemingly resurrected, integrated the deceased into the community while simultaneously ushering the dead person out of it. Such amusements demonstrated through the 'rite of passage, that the dead person had acquired a new social status' (Harlow 2003, 83). The corpse was an 'active participant in an alliance with prankster-protagonists who perpetrated jokes against an unknowing side' which was 'shocked by the rising corpse, the corpse's greeting, the corpse's voice. The corpse was so much a part of the frivolity that he "willingly allowed his toes to be bitten by the 'victim' of 'forfeits'”' (Narváez 2003, 121).

In the half-dark of the wake house, 'tobacco and whiskey were freely provided, there was a great deal of noise and sexual pairings, and various games were played' (Bourke 1993, 162). Ó Súilleabháin (1967) has detailed numerous playful wake jokes which included tying together the shoelaces or coat-tails of the elderly, putting tobacco into the teapot, pricking people with pins or needles, sewing the coat-tails of the intoxicated to the shroud of the corpse, binding those who fell asleep then blackening their faces with polish or soot or shaving off their beards; however, the games which caused the most outrage to outside observers were those with sexual overtones. Prim $(1853,334)$ gave an account of a game called 'Bout' which was played by men and women but he fails to describe it in detail as all of the participants 'acted a very obscene part which cannot be described'. The game, 'The Bull and the Cow', is described by Ó Súilleabháin (1967) as a game where the player has to break in or out of the circle, in this case to kiss the girl seated on another man's knees. However, this would appear to be an adaptation of a much older ritual where men and women, clad in hides and horns as bulls and cows, fight resulting in the cow being captured (Wilde 1971 [1887], 123). This is possibly a reference to The Tain Bó Cúalnge or Cattle Raid of Cooley, where cattle were stolen for their value as currency. In the game, Drawing the Ship out of the Mud, the men engaged in the performance, 'actually presented themselves before the assembly, females as well as males, in a state of nudity' (Prim $\underline{1853}$, 334); while in 
another instance, a gentleman who was collecting accounts of 'wake orgies' mentions the dance Droghedy which he classifies as 'highly obscene' and 'very objectionable' (WoodMartin 1901, 321). Irish writer, William Carleton $(\underline{1869}, 158)$, comments on the types of dances he observed at wakes in those 'remote parts of the country where funeral customs are pertinaciously clung to' as having a 'Druidic or Magian descent'. He describes one such dance which was 'not necessarily performed to music and could not be danced without the emblematic aids of a stick and a handkerchief' as being 'addressed to an individual passion' and 'one of those symbolic dances which were used in pagan rites'. Holst-Warhaft (2000, 701) states that, while this description is 'coy', there can be little doubt that 'phallic dances were performed at wakes and that the association of the wake with sexuality was explicit', reinforcing the notion of the cycle of life and death.

\section{Female vocality and the liminal}

The unbridled extravagances of wake amusements created an 'aesthetic of excess' where the 'dialectic of comedy and tragedy resolved itself temporarily into a higher unity in the concept of carnival' (Doyle 1988, 127). At the centre of this 'topsy-turvy' world were women, whose function was central to the grieving process, from the 'laying out' of the body to the ritual caoineadh which marginalized the bean chaointe from the community and allowed her to create a liminal space for the period of mourning. The keening woman is described in lament texts as in a state of assumed madness and Bourke (1993) cites evidence that attests to the keener's state of 'otherness', describing the bean chaointe as barefoot, dishevelled, her hair uncombed, her clothing torn, her breasts bared as she travels across the untamed countryside, not on the roads which have been imposed on the landscape by the community. The keener immediately leaves whatever task she is performing in order to attend the death bed. Bourke (1993) cites the instance of Dermot McCarthy's mother, who, on hearing of her son's death, walked twenty miles over rough mountainside while still holding the rope she used to tie her cow. The bean chaointe also uses her poetry to reclaim nature as a witness to the chaos imposed by death, saying for example that 'the birds have fallen silent' (Bourke 1988, 289). The keener is imbued with a kind of holy madness and often drinks the blood of the deceased. This association with blood is a common theme and there are several examples, most notably in 'The Lament for Art O'Leary', where his wife, Eileen O'Connell (1987, 52), drank his blood from her palms. In the eighth stanza she proclaims:

Your heart's blood was still flowing:

I did not stay to wipe it

But filled my hands and drank it.

As a lamenting woman, O'Connell 'symbolically both reclaimed him (by drinking his blood) and enabled him to integrate with his ancestors’ (Lysaght 1997, 75). This reference to the ritual of blood drinking occurs in other stories in Irish literature, for example in Deidre's 'Lament for the Sons of Uisneach' and Emer's 'Lament for Cú Chulainn'.

The assumed madness of lamenting women also allowed them to make covert statements about personal and sexual identity. The guise of the keening woman with her unbound hair and bared breasts challenged the accepted norms of the woman in Irish society and this was further reinforced by references in laments to sexual pleasure, or the lack of it, with husbands, as well as comments on pregnancy and childbirth (Bourke 1993, 166). Angela Partridge (1980) in Wild Men and Wailing Women suggests that keeners in this state of divine madness are indicative of people in transition, or outside the normal structure of society, a state necessary in order for the bean chaointe to step across the divide, away from the living, in order to escort the souls of the dead to the other world. This separation from the world of the living gave the lamenter licence to express anger as well as grief while not having to suffer 
repercussions for her boldness after the deceased was interred. Thomas Crofton Croker (1969 [1824], 180) cites an example of lament entitled the 'Smith's Keenan' in which a sister comes accidentally on the wake of her brother and upbraids his widow in excoriating fashion:

You woman, his wife! My brother's wife, you woman with the dry eyes; you woman who are both dumb and deaf; go home! Go anywhere, leave your husband to me, and I will mourn my brother.

You woman above with the dry eyes! My brother's wife, come down and I will keen you; you will get another husband if you are young enough: but I can never get another brother!

As well as venting anger on relatives of the dead, the corpse was often the centre of criticism. In some instances the caoineadh was also used to criticize another family member as in the case of 'The Lament for Dermot Carthy', as cited by Angela Bourke (1993, 171), where the lament poet uses her son's death as a chance to criticize her son-in-law's treatment of her daughter. She sarcastically addresses him with affection, and then curses him in an elaborate fashion, shaming him before the assembly at the wake:

My love and my treasure!

I gave you presents -

Twenty dairy cows,

A trough to knead bread -

My curse on you instead,

Not on livestock or harvest,

On hearth or on home,

But in your heart and veins,

To leave you maimed,

You sour-tempered lout!

Given the strictures of religion in nineteenth-century Ireland, especially with regard to women, the voice of the keener cuts across the normal boundaries of time and space, harking back to a time when the power of the female voice mediated directly between the world of the living and the dead. Vivian Mercier $(1962,56)$ describes the Irish as 'the most archaic and conservative in Western Europe' but suggests that 'death, as we have seen in the wake games, implies sex and offers an incitement to reproduction'. He further argues that this connection is perhaps exemplified by stone carvings known as Sheela-na-gigs. These carvings are common on the exterior of churches, castles, and other buildings in Ireland and depict the figure of a skeletal woman with a skull-like head and 'huge genitalia, held open with both hands', thus combining 'sexual potency and death' (Holst-Warhaft 2000, 71). The merry wake with its tricks and fun has a similar effect as the Sheela-na-gig with her death like figure and her 'distended fount of pleasure and fruitfulness' which induces laughter from sheer relief (Mercier 1962, 56).

\section{Conclusion}

This article has explored the connection between the power of the keening woman's voice and its ability to open a dimension where licentiousness and erotic play were seen as 'normal' within the confines of the wake house. In a devoutly Catholic country such as Ireland, it is surprising that erotic pagan wake games were played in the eighteenth and nineteenth century, with some vestiges still apparent well into the twentieth century. During my field work in Ireland, I have interviewed several women in their 80s who remember the merry wake ritual with great fondness, reminiscing about the 'eating and drinking', 'matchmaking', 'games', and 'carryings on'. None of those interviewed saw any conflict between the behaviour of individuals in the wake house and the religious burial rites conducted by the priest, confiding that they were quite separate and nothing to do with each other. It is this 
very delineation between the world of the living and the world of the dead which harks back to the voice of the traditional keening woman. The power of the female voice in the liminal world cannot be underestimated as it facilitated the conclusion of the wake ritual, which allowed the community to resume its normal pattern of life having expressed its grief and joy towards the chaotic nature of death. Though the practice of keening and the merry wake has faded there are remnants of this once robust ritual which linger in parts of Ireland where the corpse shares the space with the living in a final farewell. This article has attempted to draw a connection between the erotic play of the merry wake and the liminal space of possibility opened by the voice of the bean chaointe.

\section{Notes}

1. This is the plural of bean chaointe or the keening woman.

\section{References}

- 1. Bakhtin, M.M. 1968. Rabelais and his world, Trans. Helene Iswolsky Cambridge, MA: MIT Press.

- 2. Bourke, A. 1988. The Irish traditional lament and the grieving process. Women's Studies International Forum, 11: 287-91. [CrossRef], [Web of Science ®], [CSA]

- 3. Bourke, A. 1993. "More in anger than in sorrow". In Feminist messages: Coding in women's folk culture, Edited by: Newlon Radnor, J. 160-82. Urbana: University of Illinois Press.

- 4. Brochmeyer, D. 2010. "The kiss of love and death: Eros and Thanatos in the opera”. In Eroticism and death in theatre and performance, Edited by: Gritzner, K. 80-94. Hatfield: University of Hertfordshire Press.

- 5. Campbell, T. and Watkinson, J. 1778. A philosophical survey of the south of Ireland, in a series of letters to John Watkinson M.D Dublin

- 6. Carleton, W. 1869. The poor scholar, Frank Martin and the fairies, the country dancing master, and other Irish tales, Dublin: James Duffy.

- 7. Carleton, W. 1990 [1842-44]. Traits and stories of the Irish peasantry, Savage, MD: Barnes and Noble.

- 8. Croker, T.C. 1969 [1824]. Researches in the south of Ireland: Illustrative of the scenery, architectural remains, and the manners and superstitions of the peasantry, New York: Barnes and Noble.

- 9. DeFaoite, D. 2004. Paranormal Ireland: An investigation into the other side of Irish life, New York: Barnes and Noble.

- 10. Doyle, M.A. 1988. Games of lamentation: The Irish wake performance tradition. PhD diss. Northwestern University Illinois

- 11. Grainger, R. 2010. The uses of chaos, Bern: Peter Lang.

- 12. Harlow, I. 2003. "Creating situations: Practical jokes and revival of the dead in Irish tradition”. In Of corpse: Death and humour in folklore and popular culture, Edited by: Narváez, P. 83-112. Logan: Utah State University Press.

- 13. Holst-Warhaft, G. 2000. The cue for passion: Grief and its political uses, Cambridge MA: Harvard University Press.

- 14. Huizinga, J. 1955. Homo ludens: A study of the play-element in culture, Boston, MA: Beacon Press.

- 15. Lysaght, P. 1996. The banshee: The Irish supernatural death messenger, Dublin: The O'Brien Press. 
- 16. Lysaght, P. 1997. Caoineadh os cionn coirp: The lament for the dead in Ireland. Folklore, 108: 65-83. [Taylor \& Francis Online], [Web of Science ${ }^{\circledR}$ ]

- 17. Lysaght, P. 2003. Hospitality at wakes and funerals in Ireland from the seventeenth to the nineteenth century: Some evidence from the written record. Folklore, 114: 403-26. [Taylor \& Francis Online], [Web of Science ${ }^{\circledR}$ ]

- 18. Mercier, V. 1962. The Irish comic tradition, Oxford: Oxford University Press.

- 19. Morris, H. 1938. Irish wake games. Béaloideas, 8: 123-41. [CrossRef]

- 20. Narváez, P. 2003. "Tricks and fun: Subversive pleasures at Newfoundland wakes”. In Of corpse: Death and humour in folklore and popular culture, Edited by: Narváez, P. 113-39. Logan: Utah State University Press.

- 21. O'Connell, E. 1987. “The lament for Art O'Leary”. In Irish literature: A reader, Edited by: O'Rourke Murphy, M. and MacKillop, J. 49-62. New York: Syracuse University Press.

- 22. Ó Crualaoich, G. 1998. “The 'merry wake’”. In Irish popular culture 1650-1850, Edited by: Donnelly, J.S. Jr. and Miller, K.A. 173-200. Dublin: Irish Academic Press.

- 23. O Madagáin, B. 2006. Hags, queens and wisewomen, [Radio interview] Radio Eire, Ireland

- 24. O Súilleabháin, S. 1967. Irish wake amusements, Dublin: Mercier.

- 25. Partridge, A. 1980. Wild men and wailing women. Éigse, 18(1): 25-37.

- 26. Prim, J.A. 1852-53. Olden popular pastimes in Kilkenny. Journal of the Royal Society of Antiquarians of Ireland, 2: 319-35.

- 27. Quealy, M. 2009. Interview by Narelle McCoy., July 7, Miltown Malbay, County Clare, Ireland

- 28. Rees, A. and Rees, B. 1961. Celtic heritage: Ancient tradition in Ireland and Wales, London: Thames and Hudson.

- 29. Ridge, A. 2009. Death customs in rural Ireland: Traditional funerary rites in the Irish midlands, Galway: Arlen House.

- 30. Squire, C. 1979 [1905]. “Celtic myth and legend, poetry and romance”. New York: Bell Publishing Company.

- 31. Synge, J.M. 1979. The Aran Islands, Edited by: Skelton, R. Oxford: Oxford University Press.

- 32. Tolbert, E. 1994. "The voice of lament: Female vocality and performance efficacy in the Finnish-Karelian itkuvirsi”. In Embodied voices: Representing female vocality in Western cultures, Edited by: Dunn, L.C. and Jones, N.A. 179-94. Cambridge: Cambridge University Press.

- 33. Wilde, Lady E. 1971 [1881]. Ancient legends of Ireland, mystic charms, and superstitions of Ireland with sketches of the Irish past, Galway: O'Gorman Ltd.

- 34. Wood-Martin, W.G. 1901. Traces of the elder faiths in Ireland: A folklore sketch. Vol. 1, A handbook of Irish pre-Christian traditions, London: Longmans, Green, and Co. 